\title{
Fabrication of thin-walled iridium tubular articles by radial magnetic pulsed compaction and sintering of nanopowder
}

\author{
V.I. Krutikov ${ }^{\dagger, 1}$, S. N. Paranin ${ }^{1}$, A. V. Spirin ${ }^{1}$, A. S. Kazakov², E. P. Aleksandrov ${ }^{2}$ \\ †krutikov@iep.uran.ru \\ ${ }^{1}$ Institute of Electrophysics UB RAS, 106 Amundsena St., Yekaterinburg, 620016, Russia \\ ${ }^{2}$ Scientific Production Association “Ural Metals" Limited Company, 115A Belinsky St., Yekaterinburg, 620142, Russia
}

\begin{abstract}
Iridium is rather difficult to process due to its brittleness and sensitivity to impurities. It is better treated while it is clean and fine-grained. Therefore, it should be promising to use fine powders. At the same time, the pressing and sintering of iridium nanopowders has not been studied well. This paper describes a method for manufacturing thin-walled iridium tubes using powder technology. Iridium powder of $99.997 \%$ purity with an average particle size of $42 \mathrm{~nm}$ (BET) was obtained by the electrolysis of molten salts. It was subjected to radial magnetic pulsed compaction in copper shell, which was subsequently chemically removed. The resulting pressure on the powder here strongly depends on the parameters of the magnetic field pulse and other initial conditions, such as the properties of the shell, the thickness of the charge and the rheological properties of the powder. Therefore, the properties of green and sintered samples were investigated depending on the amplitude of the magnetic pressure, without changing the other parameters. Green bodies with a relative density of up to $50 \%$ were obtained with an amplitude of magnetic pressure of 85-190 MPa. The green density slightly increased with increasing magnetic pressure. Sintering at $1000^{\circ} \mathrm{C}$ in a hydrogen atmosphere yielded thin-walled tubes with a grain size of $0.3 \mu \mathrm{m}$ and a density of up to $22.3 \mathrm{~g} / \mathrm{cm}^{3}$, close to the theoretical density of iridium, $22.56 \mathrm{~g} / \mathrm{cm}^{3}$. The sintered density was insensitive to the green density in the studied range. Solid sintered tubes were obtained by an amplitude of magnetic pressure between 85 and $122 \mathrm{MPa}$.
\end{abstract}

Keywords: iridium nanopowder, magnetic pulsed compaction, sintering.

УДК: 621.762 .4

\section{Получение тонкостенных труб из иридия с применением магнитно-импульсного прессования и спекания нанодисперсного порошка}

\author{
Крутиков В. И. ${ }^{\dagger}$, , Паранин С. Н. ${ }^{1}$, Спирин А. В. ${ }^{1}$, Казаков А. С. ${ }^{2}$, Александров Е. П. ${ }^{2}$ \\ ${ }^{1}$ Институт электрофизики УрО РАН, ул. Амундсена, 106, Екатеринбург, 620016, Россия \\ ${ }^{2} \mathrm{OOO}$ «Научно-производственное объединение «Металлы Урала», ул. Белинского, 115А, Екатеринбург, 620142, Россия
}

Иридий довольно сложен в обработке ввиду его хрупкости и чувствительности к примесям. Он лучше поддаётся обработке в очищенном и мелкозернистом виде. Поэтому должно быть перспективным применение мелкодисперсных порошков. При этом прессование и спекание нанопорошков иридия пока мало изучено. В данной работе описан способ изготовления тонкостенных труб из иридия по порошковой технологии. Порошок иридия чистотой 99.997\% со средним размером частиц 42 нм (БЭТ) был получен электролизом расплавленных солей. Его подвергали радиальному магнитно-импульсному прессованию в медной трубчатой оболочке, которую впоследствии химически удаляли. Давление прессования здесь сильно зависит от параметров импульса магнитного поля и от других начальных условий, таких как свойства оболочки, толщина засыпки и реологические свойства порошка. Поэтому свойства изделий исследовали в зависимости от амплитуды магнитного давления, не меняя остальных параметров. Прессование с амплитудой магнитного давления 85-190 МПа и длительностью импульса около 100 мкс позволило получить компакты с относительной плотностью до $50 \%$. Плотность компактов незначительно увеличивалась с увеличением магнитного давления. Спеканием при $1000^{\circ} \mathrm{C}$ в атмосфере водорода были получены тонкостенные трубки с размером зерна 0.3 мкм и плотностью до 22.3 г $/ \mathrm{cm}^{3}$, близкой к теоретической плотности иридия, 22.56 г $/ \mathrm{cm}^{3}$. Плотность спеченных образцов не зависела от плотности компактов в исследованном диапазоне. Цельные спеченные трубы были получены при прессовании с амплитудой магнитного давления в 85-122 МПа.

Ключевые слова: нанопорошок иридия, магнитно-импульсное прессование, спекание. 


\section{Introduction}

Global consumption of iridium increases over the years, and the range of iridium products also increases $[1,2]$. It is widely used for crucibles, containers and seed holders in growing crystals, spark plug electrodes, etc., due to its unique properties, such as high melting point and resistance to chemical erosion [3]. Iridium tubular articles may be used in various engineering fields, for example, as W-Ir nozzles in the production of ceramic refractory fiber. However, few works have studied thin-walled iridium tubes. Usually, the production of such tubes requires electron beam melted [4] or vacuum arc remelted [5] ingots, which are subsequently hotrolled, formed into tubes and arc welded [6]. Technological routes for casting such products are quite expensive due to their complexity. The main point here is that iridium is brittle even with a small amount $(0.2 \%)$ of impurities [1]. However, being purified it can be hot worked [7] or even plastically deformed at room temperature [8]. In [1] it was considered to be better mechanically treatable in a fine-grained state.

Powder metallurgy, as an alternative way, is able to process pure iridium and its alloys in a fine-grained state. Crucibles for growing single crystals [9] and electrodes for plasma cutting of iridium-based alloys [10] were manufactured by means of hot isostatic pressing. The Ir-based alloys containing up to $15 \%$ alloy additions of niobium, titanium, zirconium or hafnium were consolidated from pre-alloyed powders using pulse electric current sintering method into homogenous specimens with a density of $98 \%$ [11]. Iridium alloy doped with 4 at.\% $\mathrm{Zr}$ and 0.3 at.\% $\mathrm{W}$ was subjected to cold isostatic pressing [12] at $200 \mathrm{MPa}$ for $60 \mathrm{~s}$, pre-sintered at $1500^{\circ} \mathrm{C}$ for $4 \mathrm{~h}$ in vacuum, and sintered at $2190^{\circ} \mathrm{C}$ for $3 \mathrm{~h}$ in a hydrogen atmosphere. The relative density there was $85 \%$ after pre-sintering and $95 \%$ after sintering. The grain sizes were 3 and $4-5 \mu \mathrm{m}$, respectively. Unfortunately, pure Ir was not amenable to pressing and sintering or hot isostatic pressing, according to [13]. The use of nanopowders can solve the problem due to their ability to low-temperature sintering.

While single publication [14] has been found so far regarding the compaction and sintering of iridium

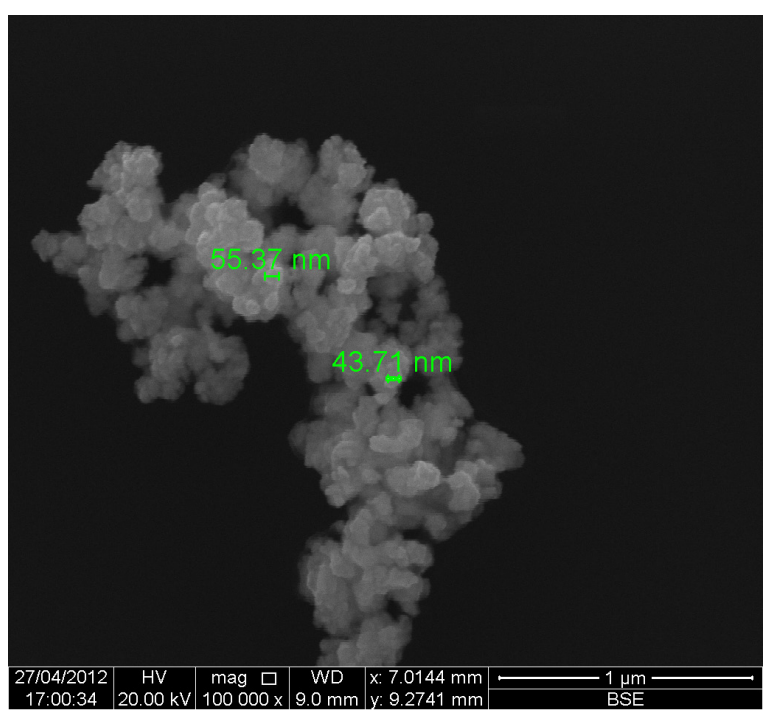

Fig. 1. SEM (a) and TEM (b) images of initial iridium nanopowder. nanopowder, this area of research will most likely grow and develop. Although nanopowders are quite difficult to compact, dynamic methods are promising for such materials $[15,16]$. In addition, the low-temperature sintering can potentially give a submicron-grained material.

The present paper describes a promising way to manufacture thin-walled tubes by radial magnetic pulsed compaction and sintering of pure iridium nanopowder.

\section{Experimental}

The initial iridium powder (Table 1) was obtained by "Ural Metals" by electrolysis of molten salts based on alkali metal chlorides [17]. After the powder had been washed from the salts, it was reduced in hydrogen at $400^{\circ} \mathrm{C}$ and cooled in argon. The chemical composition of powder and sintered samples was determined by atomic emission spectral analysis and spark mass spectrometry. The specific surface was determined by the BET method (Tristar 3000). The phases of the powder and sintered samples and the structural parameters were refined by XRD analysis (Bruker D8 Discover).

The powder consisted of faceted particles ranging in size from 15 to $50 \mathrm{~nm}$ (Fig. 1a,b). Its tap density after vibration loading (Table 1) was calculated as $\rho_{\text {tap }}=m / V$. The average mass of the powder $m$ and mold void volume $V$ were $1.6 \mathrm{~g}$ and $1.08 \mathrm{~cm}^{3}$, respectively. In relation to the theoretical density of iridium of $22.56 \mathrm{~g} / \mathrm{cm}^{3}$ [18], the tap density was only $7 \%$. Such a low density of the powder along with its micrographs indicated a high agglomeration of particles.

Table 1. Initial powder characteristics.

\begin{tabular}{|c|c|c|c|c|c|}
\hline $\begin{array}{c}\text { Ir content, } \\
\text { mas.\% }\end{array}$ & $d_{x^{\prime}, \mathrm{nm}}$ & $S_{\mathrm{BET}}, \mathrm{m}^{2} / \mathrm{g}$ & $d_{\mathrm{BET}}, \mathrm{nm}$ & $\rho_{\text {tap }}, \mathrm{g} / \mathrm{cm}^{3}$ & $\rho_{\text {tap rel }} \%$ \\
\hline 99.997 & 17 & 6.4 & 42 & 1.52 & 6.7 \\
\hline
\end{tabular}

Notes: $d_{x}$ is the crystallite size; $S_{\mathrm{BET}}$ is the powder specific surface; $d_{\mathrm{BET}}$ is the average particle size; $\rho_{\text {tap }}$ is the tap powder density; $\rho_{\text {tap rel }}$ is the tap powder density in relation to the theoretical density, $22.56 \mathrm{~g} / \mathrm{cm}^{3}$.

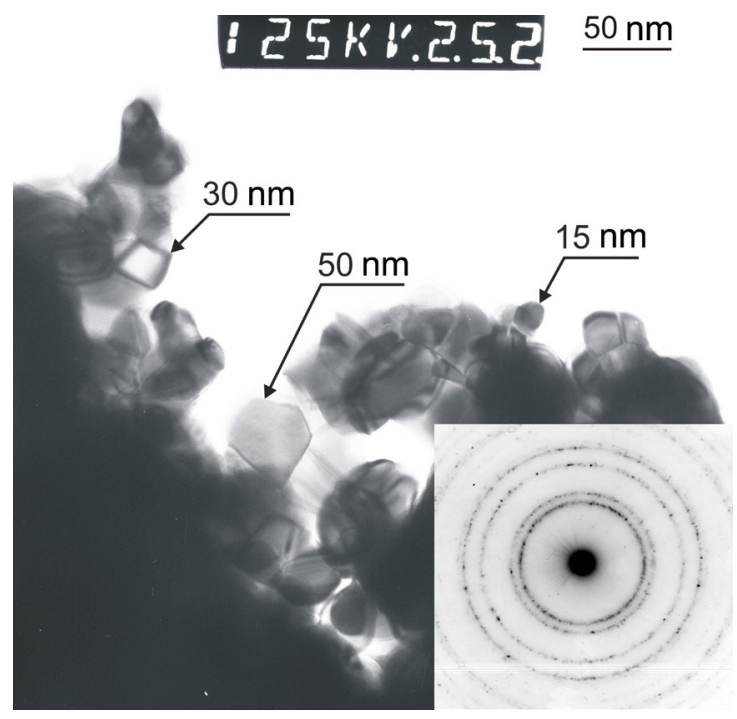

b 
The powder densification curve (Fig. 2) was obtained by uniaxial static pressing of powder cylinders of $0.64-0.68 \mathrm{~g}$ in the mold with a diameter of $4.5 \mathrm{~mm}$ at pressures from 0.07 to $1 \mathrm{GPa}$. The maximum relative green density of $46 \%$ was achieved.

Radial magnetic pulsed compaction $[15,19,20]$ was carried out on a pulsed current generator with a $425 \mu \mathrm{F}$ capacitor battery and a maximum charging voltage of $25 \mathrm{kV}$. The generator was loaded on a multi-turn inductor. The total inductance of the discharge circuit with this inductor was about $2.5 \mu \mathrm{H}$. The inductor was a solid spiral made of hardened structural steel. Its turns had a rectangular cross-section of $5.6 \times 27.1 \mathrm{~mm}$, the spiral step was $6.2 \mathrm{~mm}$. The internal diameter of the inductor was $25.8 \mathrm{~mm}$; its length was $152 \mathrm{~mm}$. The turns were insulated with glass fiber reinforced epoxy resin.

A specially designed mold was placed inside the inductor (Fig. 3 a). The powder (1) was filled into the gap between the copper shell (2) and the copper core (3) using an additional holder. The inductor was several times longer than the copper tube: this ensured the magnetic field uniformity along the tube. The outer diameter of the copper shell was $12 \mathrm{~mm}$ and its wall thickness was $0.9 \mathrm{~mm}$. The core diameter was $6 \mathrm{~mm}$. Thus, the initial powder filling thickness was $2.1 \mathrm{~mm}$. The powder was loaded using a vibrating table for 5 minutes. The advantage of this mold design is that the non-fixed ends of the copper tube slide over the stainless steel plugs (4); in this way powder compression circumstances are quite uniform along the tube. Due to the elimination of the edge effects, the powder is used with minimal losses.

The powder was degassed by placing the mold into an additional thin-walled stainless steel tube (not shown in the Fig. $3 \mathrm{a}$ ). Pumping was carried out at $160-170^{\circ} \mathrm{C}$ for 45-60 minutes to a residual pressure of 5-10 Pa. Magnetic pulsed compaction was carried out inside the same stainless steel tube after cooling to room temperature under continuous pumping.

The current pulse for the compaction was one half-wave of a damped sinusoid, $108 \mu$ s in duration (Fig. $3 \mathrm{~b}$ ). It was measured using a Rogowski coil. Here the charging voltage was $10 \mathrm{kV}$. The current switching off at its zero is the result of the diode effect in the vacuum spark switches [21] used in the generator power circuit. The stainless steel tube surrounding

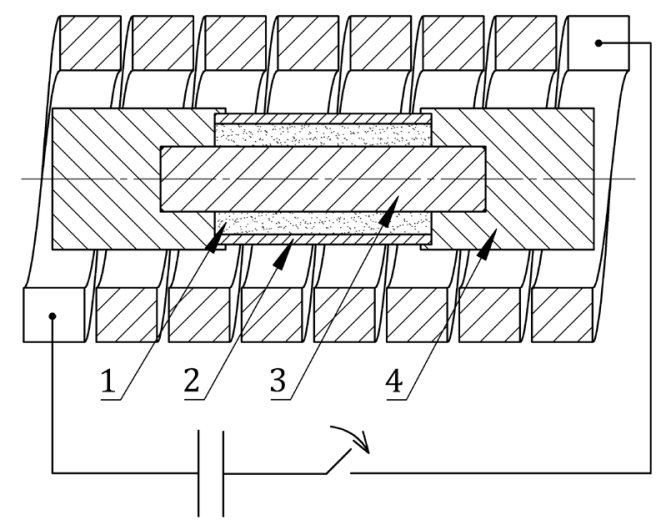

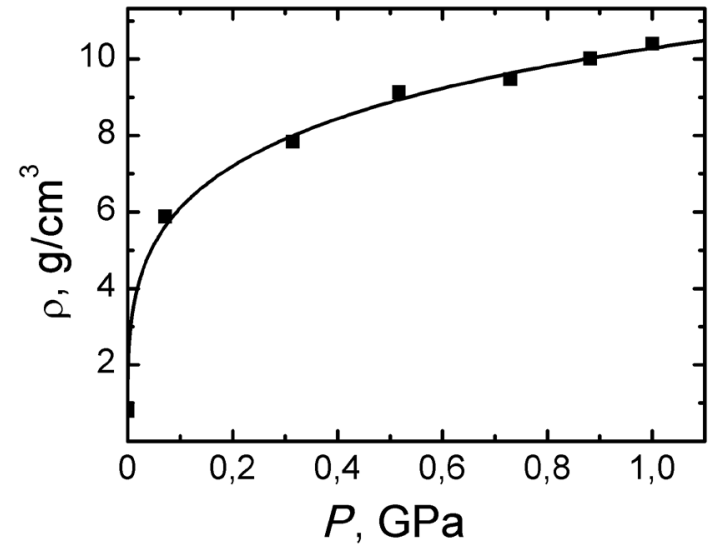

Fig. 2. Powder densification curve: green density $\rho$ versus pressure $P$. Dots - experimental data.

the mold had a diameter of $20 \mathrm{~mm}$ and a thickness of $1 \mathrm{~mm}$. It lets passing inside $87 \%$ of the coil magnetic field, which referred to the effective magnetic pressure. This diffused field was shielded by a high conductive copper tube, which resulted in radial compressing the tube and the powder inside as a consequence. It should be noted that in dynamic methods the low tap density of the powder allows achieving high kinetic energy of the tube wall. At further compaction stages, this energy goes to the powder densification (inertial effect). The dependence of the green density on the amplitude of the magnetic pressure was discovered with fixed other parameters.

The magnetic pressure was varied by changing the battery charging voltage from 10 to $15 \mathrm{kV}$, which refers to a magnetic field from 15 to $22 \mathrm{~T}$, magnetic pressure from 85 to $190 \mathrm{MPa}$ and maximum tube velocity from 90 to $160 \mathrm{~m} / \mathrm{s}$, as was calculated according to the model from [16]. The green density was determined using the actual powder tap density and size reduction after pressing.

To extract the sample, the copper shell and core were removed by etching in dilute nitric acid, as in [19]. The compacts were then washed from the acid with distilled water. The dried samples were sintered in hydrogen at $1000^{\circ} \mathrm{C}$ for 30 minutes at a maximum heating rate of $3^{\circ} \mathrm{C} / \mathrm{min}$. Then they were cooled in argon at $5^{\circ} \mathrm{C} / \mathrm{min}$. The density of the sintered samples was determined by weighing in water.

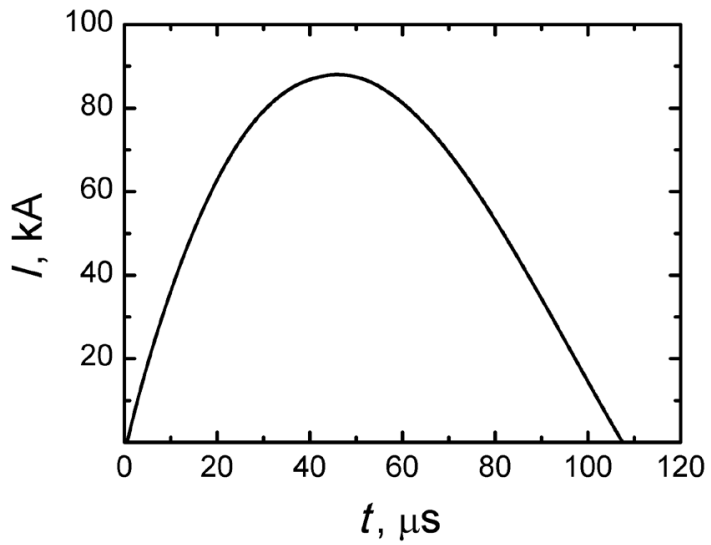

b

Fig. 3. Magnetic pulsed compaction scheme (a) and typical pulse of current at $10 \mathrm{kV}$ charging voltage (b). 1 - powder, 2 - copper tube, 3 - copper rod, 4 - end plug. 


\section{Results and discussion}

The initial powder was compacted to a relative density of $35-50 \%$ by radial magnetic pulsed compaction (Fig. 4) with an amplitude of magnetic pressure of $85-190 \mathrm{MPa}$. The copper shell here acts as a "magnetic hammer", therefore the inertial effect results in several times higher compacting pressure on the powder. If the powder is compacted from low tap density (Table 1), the powder exerts low resistance at the beginning of the shell compression. This allows the shell to reach higher velocities, therefore, increasing the pressure on the powder. The green density slightly increased with increasing amplitude of magnetic pressure. The density of the sintered tubes was about $22.3 \mathrm{~g} / \mathrm{cm}^{3}$, regardless of the green density in the studied range.

The dimensions of the compacts (Fig. $5 \mathrm{a}, \mathrm{b}$ ) were: $6.8 \mathrm{~mm}$ in external diameter, $0.4 \mathrm{~mm}$ in wall thickness and $20 \mathrm{~mm}$ in length. The shell and compact were pressed quite uniformly along the axis.

Solid sintered products were obtained with amplitudes of magnetic pressure from 85 to $122 \mathrm{MPa}$ (Fig. 5c). Their dimensions were: $4.9-5.2 \mathrm{~mm}$ in external diameter, $0.35-0.38 \mathrm{~mm}$ in wall thickness, $13-14 \mathrm{~mm}$ in length. Relative diameter difference (ellipticity) after sintering in the middle and the ends of the best obtained tubes did not exceed 1\%.

Cracks emerging on the samples compacted with higher magnetic pressures (Fig. $5 \mathrm{~d}$ ) most likely resulted from overpressing: excessive internal stresses in the compacts, which led to the fracture of the material during sintering.

An average grain size of $0.3 \mu \mathrm{m}$ was measured on SEM-images of the fractured sintered sample using the linear

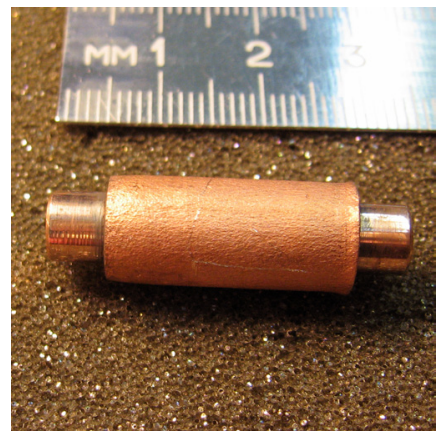

a

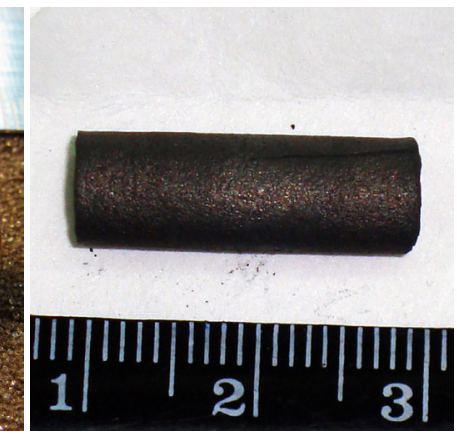

b

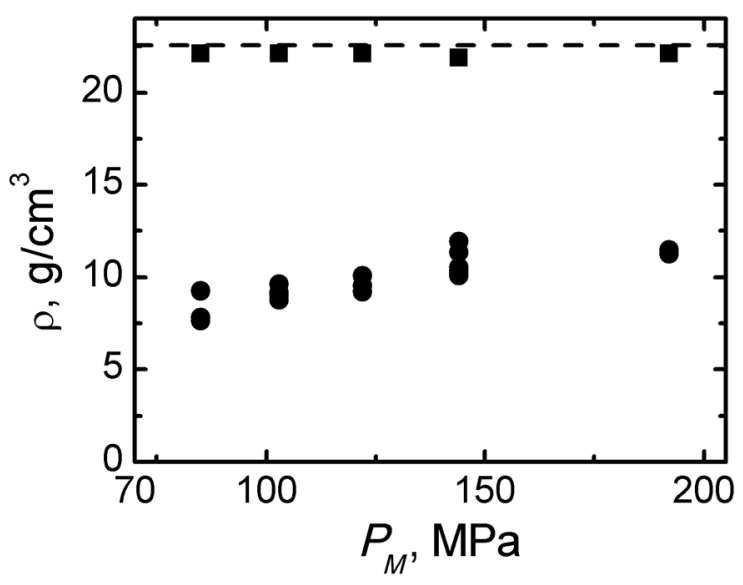

Fig. 4. Green densities (round markers) and sintered densities (square markers) versus magnetic pressure. Theoretical density of iridium is shown by a dashed line.

intercept method (Fig. 6a). At the same time, X-ray diffraction (Fig. 6b) indicated single-phase cubic iridium (Fm-3m spatial group) with a lattice period of $0.38404 \pm 0.00005 \mathrm{~nm}$ and an average crystallite size of $180 \pm 15 \mathrm{~nm}$.

The amount of impurities after compaction and sintering increased in comparison to that in the initial powder: $88 \mathrm{ppm}$ of impurities were registered, in particular 57 ppm of copper, $15 \mathrm{ppm}$ of silicon, and $8 \mathrm{ppm}$ of each silver and zinc. Thus, the iridium nanopowder was compacted and sintered to $99.99 \%$ Ir with a smaller grain size and a higher density than its alloy with 4 at.\% $\mathrm{Zr}$ and 0.3 at.\% $\mathrm{W}$ by cold isostatic pressing and sintering performed in [12].

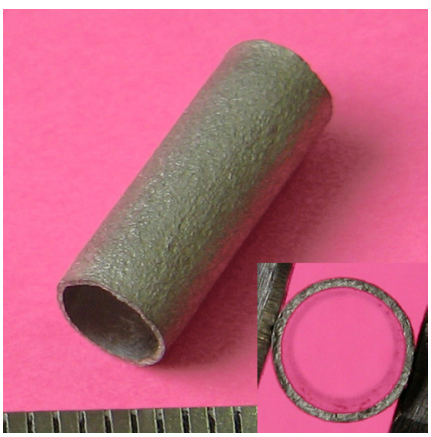

c

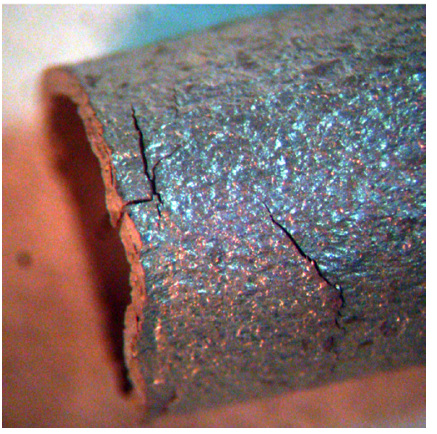

d

Fig. 5. (Color online) The view of the compact inside the shell (a), extracted compact (b), sintered samples obtained at different magnetic pressures: $100 \mathrm{MPa}$ (c); $140 \mathrm{MPa}(\mathrm{d})$.

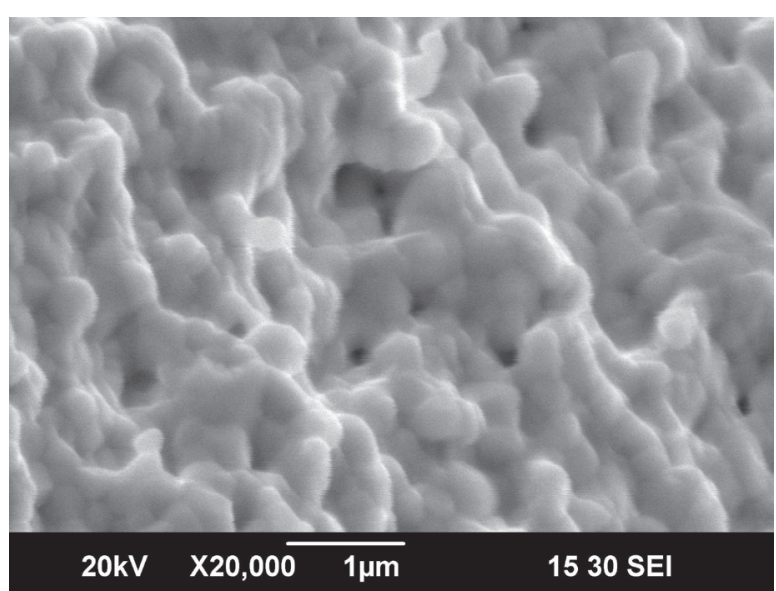

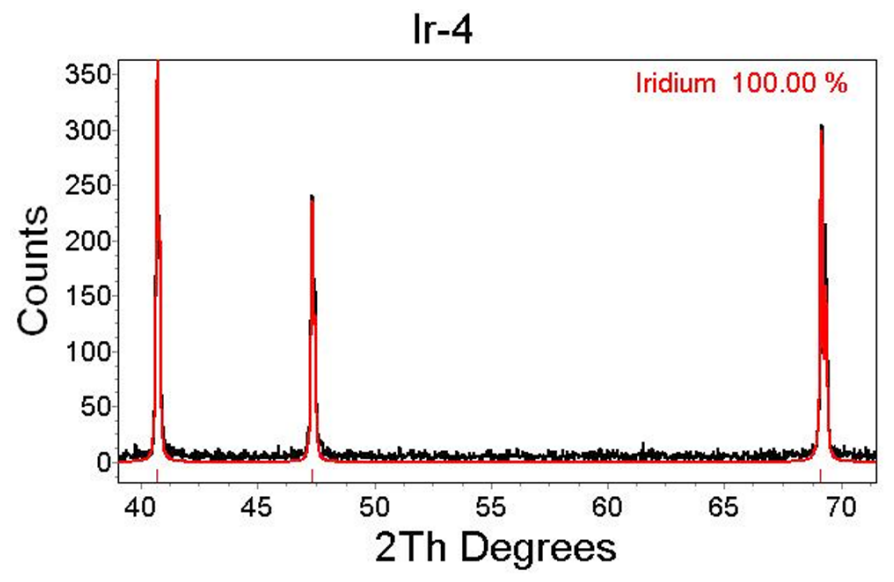

$\mathrm{b}$

Fig. 6. Sintered sample: SEM of the fracture (a); X-ray diffraction pattern (b). 


\section{Conclusion}

The initial nanopowder of pure iridium was subjected to radial magnetic pulsed compaction. Green bodies with a relative density of up to $50 \%$ were obtained. Due to the geometry and inertial effect, peak magnetic pressure of 85-190 MPa was needed instead of a static uniaxial pressure of more than $1 \mathrm{GPa}$. The chosen mold design allowed us to minimize the powder losses. The green density slightly increased with increasing amplitude of magnetic pressure. A magnetic pressure of $85-122 \mathrm{MPa}$ was sufficient to produce solid sintered tubes. Sintering at $1000^{\circ} \mathrm{C}$ in a hydrogen atmosphere yielded thin-walled tubes with a grain size of $0.3 \mu \mathrm{m}$, having a density close to the density of the solid body, up to $22.3 \mathrm{~g} / \mathrm{cm}^{3}$, which was insensitive to the green density in the studied range. A further increase in pressure led to cracking during sintering.

The use of a radial magnetic pulsed compaction in a copper shell with its subsequent etching allows forming both tubes and other axisymmetric products with varying diameters or wall thicknesses, such as a nozzle. This technology is reasonable for iridium and other acid-resistant materials, when the final product is more expensive than copper shell.

\section{References}

1. A. V. Ermakov, S.S. Naboichenko. Russ J Non-Ferr Met+. 53 (4), 292 (2012). Crossref

2. E. K. Ohriner. Platin. Met. Rev. 52 (3), 186 (2008). Crossref

3. L. B. Hunt. Platin. Met. Rev. 31 (1), 32 (1987).

4. E. K. Ohriner. J. Alloys Compd. 461 (1-2), 633 (2008). Crossref

5. R. L. Heestand, E. K. Ohriner. J. Met. 40 (7), A63 (1988).

6. N. I. Timofeev, A. V. Ermakov, V. A. Dmitriev, P. E. Panfilov. Osnovy metallurgii i tekhnologii proizvodstva izdeliy iz iridiya. Yekaterinburg, Ural Branch of RAS (1996) p. 105 -109. (in Russian) [Н. И. Тимофеев, А. В. Ермаков, В. А. Дмитриев, П.Е. Панфилов. Основы металлургии и технологии производства изделий из иридия. Екатеринбург, УрО РАН (1996) с. 105 -109.]
7. E. P. George, C.G. McKamey, E.K. Ohriner, E.H. Lee. Mater. Sci. Eng. A. 319-321, 466 (2001). Crossref

8. P. Panfilov, A. Ermakov, O. V. Antonova, V.P. Pilyugin. Platinum Metals Rev. 53 (3), 138 (2009). Crossref

9. B. Cockayne. Platin. Met. Rev. 18 (3), 86 (1974).

10. M. Ushio, K. Kusumoto, F. Matsuda. International Trends in Welding Science and Technology. Gatlinburg, Tennessee, U.S. A. (1993) p. 365.

11. C. Huang, Y. Yamabe-Mitarai, H. Harada, J. Mater. Eng. Perform. 11 (1), 32 (2002). Crossref

12. C. Xiang, Y. Ge, H. Liu, Y. Huang, H. Tang. Rare Metal Mat Eng. 38 (7), 1132 (2009). Crossref

13. D. Lupton, M. Hörmann. Galvanotechnik. 87 (1), 72 (1996).

14. Patent RF № 2633203, 11.10.2017. (in Russian) [Патент РФ № 2633203, 11.10.2017.]

15. S. N. Paranin, V. V. Ivanov, A. V. Nikonov, A. V. Spirin, V. R. Khrustov, S. Yu. Ivin, A. S. Kaygorodov, P. N. Korolev. Adv Sci Tech. 45, 899 (2006). Crossref

16. G. Sh. Boltachev, K.A. Nagayev, S.N. Paranin, A.V. Spirin, N.B. Volkov. Magnetic Pulsed Compaction of Nanosized Powders. New York, Nova Science Publishers Inc. (2010) 86 p.

17. N. I. Timofeev, O. Yu. Afanasyev, L.D. Gorbatova, E.P. Aleksandrov, A.V. Vasilyev, A.S. Kazakov. Proceedings of XIX International Chernyaev Conference on Chemistry, Analytics, and Technology of Platinum Metals. Part 2. Novosibirsk (2010) p. 79. (in Russian) [Н.И. Тимофеев, О.Ю. Афанасьев, Л.Д. Горбатова, Е.П. Александров, А.В. Васильев, А.С. Казаков. Сборник трудов XIX Международной Черняевской конференции по химии, аналитике и технологии платиновых металлов. Ч. 2. Новосибирск (2010) с. 79.]

18. International Centre for Diffraction Data (ICDD), PDF-2 database. Pattern 00-006-0598.

19. US Patent No. 3346914, 17.10.1967.

20. V.A. Mironov. Magnitno-impul'snoye pressovaniye poroshkov. Riga, Zinatne (1980) 196 p. (in Russian) [B.А. Миронов. Магнитно-импульсное прессование порошков. Рига, Зинатне (1980) 196 с.]

21. Website: characteristics of RVU-47 vacuum switches (manufacturer is LLC VEI-AVIS) 